IJLRES - International Journal on Language, Research and Education Studies

ISSN: 2580-6777 (p); 2580-6785 (e)

Vol. 1, No. 1, 2017

Page: $34-52$

\title{
THE SYSTEM OF SPIRITUAL EDUCATION OF TAREKAT SAMMANIYAH AT LEARNING ASSEMBLY OF IHYA ULUMUDDIN MEDAN
}

\author{
Arifin \\ School of Postgraduate, State Islamic University of North Sumatra \\ email: arifin@gmail.com \\ Hasan Asari \\ State Islamic University of North Sumatra \\ Amroeni Drajat \\ State Islamic University of North Sumatra.
}

\begin{abstract}
This study aimed to discover 1) the goal of spiritual education of Tarekat Sammaniyah at Learning Assembly of Ihya Ulumuddin Medan, 2) the contents of spiritual education of Tarekat Sammaniyah at Learning Assembly of Ihya Ulumuddin Medan, 3) The Method of spiritual education of Taretkat Sammaniyah at Learning Assembly of Ihya Ulumuddin Medan, 4) The teachers/ Fasilitators of spiritual education of Tarekat Sammaniyah at Learning Assembly of Ihya Ulumuddin Medan, 5) The Students of spiritual education of Tarekat Sammaniyah at Learning Assembly of Ihya Ulumuddin Medan, 6) Facilities and infrastuctures of Tarekat Sammaniyah at Learning Assembly of Ihya Ulumuddin Medan. This study used the qualitative research approach. The data was taken through intervew, observation and also takng documentation. The informan of this study was the principle concurently teacher (Called by Mursyid), Assistant of teacher (called by Khalifah), Students (Called by Salik) of Tarekat Sammaniyah at Learning Assembly of Ihya Ulumuddin Medan. The data analysis was done by data reduction, presentation of the data and data verification. The results of this study were; 1) The aim of spiritual education was to know Allah, to remember, and also to look Allah by purification of the soul (Tazkiyatun Nafsi) and draw closer to the God (Allah) by cleansing the heart (Taqorrub Ilallah), 2) The contents of spiritual education were about Islam, faith, goodness, Syari'at, Hakikat, Ma'rifat and also Zikir (Remember of the God), 3) The method were bai'at, lecturing, remembering (rabithah, kafi'at, tawajjuh, khalwat/suluk), 4) The Mursyid was one who led and taught and also developed the Tarekat, he has an unbroken lineage up to Prophet, Jibril and Allah SWT. The level were; Syekh/Buya/Father, Vice Mursyid (Khalifah), Firstly, the Old Khalifah, Secondly, The young Khalifah. The qualities that must be possessed by the Mursyid / vice Mursyid were namely: pious, wise, be patient and merciful nature, able to keep secrets, trust, discipline, guarding the lust of the worldly desire, sincere heart, should not be disappointed seeing the students who have not succeeded yet, Maintaining self-esteem, prestige, may provide certain clues in certain circumstances, 5) The Students were people who have been sworn, and before being sworn, they should bathe taubat, pray taubat, and also pray hajat to study knowledge to Mursyid. The level of students/Salik were mubtadi, mutawashithah, muntahi, 6) The facilities and infrastructures were Mosque, The Guest room for whom it may stay overnight, sound system, Suluk place, ablution place, tasbih, curtain for seclusion (khalwat).
\end{abstract}

Key Words: Spiritual Education, Tarekat Sammaniyah 


\section{INTRODUCTION}

The raising of spiritual education terminology may be a lot of proponent and contra for several reasons, although Islamic education is firmly closely related to spiritual / spiritual education. One of them according to the author is a concrete definition of the spiritual education it. ${ }^{\text {This }}$ was because the spirit or the soul can be educated like physically of human being. In spite of it all, the spiritual abstract according to the author, can be educated by tazkiyatunafs or soul-purifying exercises such as with many remembrance, and exercises which in the tradition of tasawuf or Tarekat are called by riyadah.

Seyyed Hossein Nasr in his book Traditional Islam in the Modern World explicitly stated that tradition implies something sacred as it is conveyed to man through revelation as well as the disclosure and development of that sacred role in the history of a particular humanity as a way of implying both horizontal continuity with the source Original and vertical connecting every pulse of tradition life that is being discussed with the meta-historical reality of transcendence. ${ }^{2}$ More explicitly, SeyyedHossein Nasr details the tradition with three traits: a holy tradition that God revealed to various religions through revelation in the context of different times and places. Tradition is always unchanged because it contains continuity, contains science of absolute reality and ways to actualize and realize knowledge in different places and time. ${ }^{3}$ Clearly tradition is a cry from the center of existence, containing metaphysical and always radiating truths that originate from transcendent reality

The Tarekat Sammaniyah has been founded by Muhammad bin Abd alKarim al-Madani al-Shafi'i al-Samman (1130-1189 / 1718-1775). He was born in

\footnotetext{
1Throughout the author's reading, a more established definition of spiritual education has not been found in some literature read, either through books or on the internet. Nevertheless, the authors conclude that spiritual education is a spiritual education that takes place in a congregation. It should be noted that the development of tarekat in the land of North Sumatra, especially Langkat and Medan have similarities in practice with the emergence of tarekat-tarekat in Indonesia as it developed until now. For more details please read Martin van Bruinessen book, TarekatNaqsabandiyah in Indonesia (Bandung: Mizan, 1996), p.15; AzyumardiAzra, Middle East Ulama Network of Archipelago Archipelago XVII and XVIII, Islamic Reform Roots in Indonesia (Jakarta: Prenada, 2004), p. 159. Islamic Encyclopedia Volume V (Jakarta: New Vision Van Hoeve, 1993), p. 66. Sri Mulyati, (et.al), Knowing \& Understanding the Muktabarah Conventions in Indonesia (Jakarta: Publisher KencanaPrenada Media Group, 2006).

${ }^{2}$ Seyyed Hossein Nasr, Traditional Islam in the Modern World. Terj.(Bandung: Pustaka, 1994), P. 3. 9.

${ }^{3}$ Seyyed Hossein Nasr, Islam and the Plight of Modern.Terj.(Bandung: Pustaka, 1994), P. 7-
} 
Medina from the Quraish family. Among his disciples and followers, he is better known by the name of al-Sammani or Muhammad Samman. Meanwhile, the IhyaUlumuddin Learning Assembly was built by SyechMuda Ahmad Arifin Al-Haj, one of the students of Syech Abdul Qadim, a developer of TarekatSammaniyah in Balubus West Sumatra. After studying for some time to get the title of Syech at the age of 33 years who is considered still too young compared to other Syech who got the title of Syech after the age old age. Precisely therefore he was held by his master SyechMuda (SyechMuda Ahmad Arifin). Syech Ahmad Arifin after obtaining the title of the Syech, returned to North Sumatra / Medan to join his elder brother a much older elder, namely Syech Ibrahim Bonjol in JalanAsrama formerly known as PondokKelapa area. Martin van Bruinessen mentions that it is not far from the outskirts of Medan, near the main road to Binjai, there is a large mosque of Syech Ibrahim Bonjol (w. 1992) an elder Minang who teaches the combined Naqsabandiyah and Sammaniyah congregations (with stronger pressure on the latter). ${ }^{4}$

The Learning Assembly of Ihya Ulumuddin Medan as an non formal education that provides religious education in accordance with the provisions of the Government based on the Law of the Republic of Indonesia Number 20 of 2003 on National Education System states that non-formal education units consist of courses, training institutions, study groups, Community learning, and majelistaklim, as well as similar educational units. ${ }^{5}$ With the recognition of the government, it would be interesting if the discussion about the spiritual education of TarekatSammaniyah in The Learning Assrmbly of IhyaUlumuddinMedan is studied more deeply, especially that as a non-formal educational institution there are several requirements which are in accordance with the limitations of education as an institution such as the purpose , Materials or curriculum, learners, educators, means of infrastructure, methods and others as agreed by education experts.

${ }^{4}$ Bruinessen, Tarekat, P. 147.

5Undang-Undang RI No. 20 tahun 2003, Bab VI Bagian Kelima Pendidikan Non formal Pasal 26 ayat 4. 


\section{LITERATURE REVIEW}

\section{The definition of Spiritual Education}

Spiritual is defined as the element contained in many other than physical that can be educated with some practice and teaching. The term spiritual is the psychological condition of a person based on the values of the divine spirit. Thus it can be interpreted that spiritual education is an attempt to nurture and give practice about morality and mind intelligence, spiritual cleanness, and spiritual calm that resides in the spiritual part of man. Spiritual education is close to Allah Almighty. After passing some practice or riyảdhah

The spiritual dimension in question is the side of the soul that has divine qualities (divinity) and has the power to attract and encourage other dimensions to realize the properties of khảliq within itself. The possession of the properties of khảliq means having inner high potency. These potentials are inherent in human psychic dimensions and require actualization. ${ }^{6}$

The spiritual word in Arabic and R̂hhaniyyah in Arabic is derived from the word "Rûh" meaning "spirit" or "spirit" which is related to the Qur'anic expression that "rûh is part of the command of my Lord." The term Rūhaniyyah or spirituality refers to what is related to the spiritual world, close to God Almighty, who is inward and often identified with eternal and eternal reality forever.7Spiritual education in the contemporary context is often identified with the coaching of human spiritual intelligence.

Ary Ginanjar defined spiritual intelligence based on the conception of Islam that spiritual education is an intelligence or ability to give meaning to the worship of every behavior and activity, through the steps and thoughts that are fitrah, to the whole person (insankamil) and have the mindset of tauhidi ( Intergalactic), and principled only to Allah SWT. ${ }^{8}$

6Baharuddin, Paradigma Psikologi Islami Studi Tentang Elemen Psikologi dari Alquran (Yogyakarta, PustakaPelajar, 2007), P. 136.

${ }^{7}$ Seyyed Hossein Nasr, Islamic Spirituality (New York: Crossroadf, 1991), P. 28.

${ }^{8}$ Ary GinanjarAgustian, Rahasia Sukses Membangun Kecerdasan Emosidan Spiritual (ESQ) Berdasarkan 6 Rukun Iman dan 5 Rukun Islam (Jakarta: Arga, 2001), P. 57. 


\section{The Purpose of Spiritual Education}

Spiritual education has a specific purpose as other aspects of Islamic education. Spiritual education is an effort to change, direct and influence the spiritual elements of learners towards the goal of education that aspired.

This is in line with the opinion of Abd al-Rahman al-Nahlawi which concludes that education has four elements, namely: a) Maintaining and maintaining the fitrah of the child before adulthood, b) Developing all potential, c) Directing all fitrah and potential to perfection, ) Implement it gradually. ${ }^{9}$

Islamic education must cover all dimensions of human meaning that education must be able to develop all dimensions that exist in man, namely physical, intellect, morals, faith, psychology, aesthetics, and social community. All human dimensions are essentially the basic potential that each individual has. Conceptually requires methods and means of education a. The methods and means of spiritual education include: a. Takhalli, Tahalli and Tajalli, b. Ta'alluq, Takhalluq and Tahaqquq, c. Ta'abud (worship), d. Praying and Remembering.

\section{The Facilities and Methd of Spiritual Education}

\section{a. Takhalli, TahallidanTajalli Method}

In the view of Sufism, if man wants to attain the degree of perfection (alInsan al-Kamil) or in another phrase called Ma'rifat (divine knowledge) where the divine dimension (Uluhiyyah) is actualized fully, man must go through a spiritual practice process called takhal- Li / zero mind process, character building (selfadornment with good behavior) and tajalli / God spot (condition where the quality of Ilahìyyah is actualized and manifested). It is informed Allah Almighty. He said:

"God inspired the soul (the path) of ungodliness and piety. Indeed, the person who purifies the soul is sincere, and surely it is the one who defiles it." (QS. AlSyams/91: 8-10).

In the interpretation explained that Allah swt. Inspires to the soul its ungodliness and piety (meaning God explains to him the path of good and evil).

${ }^{9} \mathrm{Abd}$ al-Rahman al-Nahlawi, Ushûl al-Tarbiyah wa Asâlibuha fî al-Bait wa al-Madrasah wa al-Mujtama' (Damsyiq: Dar al-Fikr, 1979), P. 13-14. 
Indeed, it is a man who sanctifies his soul from sins. And in fact it is the one who defiles it and taunts it with immoral acts. 10

Based on the verses and exegesis mentioned that Allah Almighty. Provide a variety of potential to humans. The human task is to use the trust of Allah given the potential. Such as cleansing the soul and not to pollute it, the Takhallimethod is to empty itself from all evil or evil in order to purify the soul. Tahalli is adorning you with good behavior, so with good behavior and do good this soul remains clean and sacred to avoid sin. While Tajalli is a condition where the quality of ilahiyyah actualized and realized

\section{b. Ta'alluq, TakhalluqdanTahaqquq Method}

The purpose of spiritual education according to KomaruddinHidayat is to get happiness spiritually then there are three ways to mememperolehnya when viewed from the perspective of Sufism, namely ta'alluq, takhalluq and tahaqquq. Ta'alluq means that a human tries to remember and raise awareness of heart and mind of man to Allah swt, consequently man can not be separated from thinking and remembrance of Allah swt. Wherever he was and whatever conditions. In other hand, takhalluq is an attempt to imitate the properties of Khaliq. This process can also be called internalizing the nature of Khaliq into human beings within the limits of humanity. The tahaqquq is an ability to actualize awareness and capacity of himself as a creature dominated by the properties of Khaliq so as to be reflected in his behavior of sacred and noble things.

\section{c. Method of Worship}

Worship according to Jalaluddin Rahmat is a method or a way for the development of awareness and appreciation of the form of Ilảhi, because the worship contains exercise (Riyadhah) for self-control ability, and by itself will develop the human spiritual intelligence. It is in worship Islam that provides the necessary spiritual practice for man. All the worship that exist in Islam such as: prayer, fasting,

${ }^{10} \mathrm{Al}$ Mahalli and alaluddin, Tafsir, P. 2730. 
pilgrimage, charity, alms and others aims to make the human spirit so as not to forget Allah SWT. Even always close to Him.11

\section{d. MetodeDzikirdan Praying}

Al-Adzkar as the plural of Dzikr means to remember Allah and pray to Him. Dzikir meant here is Dzikir to Allah swt. By praising, praising, and praising Him by calling Asma'ulHusna and His Supreme attributes on condition of presenting the heart. ${ }^{12}$

There are two kinds of Dzikir: Dzikir with heart and Dzikir with oral. These two Dzikir must be done to strengthen the soul and cleanse it of various impurities. As for al-Ad'iyah, the plural of $A d-D u^{\prime} a$, in this context means "to plead Allah Almighty" or "to ask for help for Him". These three things, namely, Dzikir, wirid, and prayer are religious demands. Therefore, doing these three things can give the effect of bringing people closer to Allah SWT, and sanctifies his soul and heart from the whisperings of Satan's seduction inherent in one's soul.

\section{METHODOLOGY}

This research was qualitative research with phenomenal approach and using descriptive method. Qualitative research is a type of research that results in discoveries that cannot be achieved (obtained) using statistical procedures or other means of quantification (measurement). One reason researchers use the phenomenal approach is that this approach can reveal the phenomena or meaning that occurred related to the spiritual education system of TarekatSammaniyah, so as to find and understand what is hidden behind the phenomenon that occurred.

Qualitative research with a phenomenological approach is to observe people in their environment interacting with them, trying to understand their language and interpretations of the world around them, approaching or interacting with people related to research focus in order to try to understand, explore their views and experiences to get information Or data required. ${ }^{13}$

\footnotetext{
11Jalaluddin, Reformasi, P. 37.

12‘Ali Abd al-Hamid Mahmud, al-Tarbiyah al-Rûhiyyah, P. 50.

${ }^{13}$ Sugiyono, Memahami Penelitian Kualitatif (Bandung: Alfabeta, 2014),cet.10, P. 2.
} 


\section{The Time of Research}

In relation to this research is the type of qualitative research so this study is not determined deadline clearly until the researcher get a really thorough understanding of the object in the perusal, but due to various considerations and any limitations of this research can be terminated and made the report, if considered Has achieved data and data analysis in accordance with the design. Nevertheless, this study remains timed, which is predicted from October 2014 until March 2017.

\section{The Subject of Research}

Researchers are the main instruments in qualitative research, performing concrete steps to research directly to the field where the research by doing the following:

1. Conduct unstructured observations and interviews which are considered more feasible, on the grounds that the researcher has a base in science relevant to the problem under study; For example if researchers master the science of education, observations and interviews conducted directly related to the object of research in the field of education. The researcher becomes an important instrument in pouring the meaning of education and as the main instrument or key instrument. The researcher conducted an interview to every informant who can give information about spiritual education at The Learning Assrmbly of Ihya Ulumuddin Medan about Spiritual Education of TarekatSammaniyah, furthermore researcher also doing observation on all activity which take place in The Learning Assembly of Ihya Ulumuddin related to Spiritual Education of Tarekat Sammaniyah

2. Seek meaning in every behavior or action of research object, so that found original understanding to problem and situation which is contextual. This method seeks to understand the meaning of human behavior in a wider and holistic context, viewed in terms of the thoughts and feelings of the respondents.

3. Triangulation, data or information from one party is verified by obtaining information from other sources. For example from a second party, a third party, and so on using different methods. The objective is to compare information about the same thing that is obtained from various parties in order to guarantee the level of trust. 
4. Using the perspective of empirics, that is to compare the views of respondents in interpreting the world in terms of its own stance. The researcher gives no view of what exists, does not generalize when entering the field, even as if not knowing anything that happens on the ground, thus, he can put understanding on the concepts adopted by participants.

5. Verify, among other things, by contradictory cases to obtain more reliable results. Researchers look for different or contradictory cases that have been found, with a view to obtaining a more accurate result of the level of confidence and covering the broader situation that makes it possible for him to integrate various cases.

6. The purposive sampling that the qualitative approach does not use random sampling does not use large populations and samples. Samples were chosen in terms of representation of research objectives.

7. Conduct analysis from beginning to end of the study. The intended analysis is to interpret the data obtained, as the embodiment that all descriptive methods and descriptions contain interpretation. It's just distinguished between descriptive data and analytical or interpretative data.

8. In qualitative research, the phenomenological approach is very dominant. The approach is done through the method of verstehen that every step taken in doing research cannot be separated from the aspect of subjectivity of human behavior. In this case, Moleong says that the phenomenologist's sought to enter the conceptual world of the subjects they studied in such a way that they were in the context of the events of human life. The verstehen approach is to provide insight into the object under study. Verstehen literally means understanding so that this study will place the position of the object under study and understand every social phenomenon.

\section{FINDINGS}

The teachings of the Tarekat Sammaniyah can be seen in his book Kanz alMa rifah which shows the teachings of Sufism. In the book Al-Banjârî describes the ordinance of remembrance as follows:

a) Before remembering, let bath first, remove any dirt attached to the body.

b) Purify from the dirty by performing ablution; And to cleanse the mind with a lot of say istighfâr and ask forgiveness to God. 
c) Wear white and white clothes and seclude in a quiet place.

d) Doing two-rakaat prayers once regards to please taufik and hidayah from Allah swt.

e) Sit cross-legged while humbling yourself to Allah swt. And facing the qibla by bringing his two palms up into his two knees, saying: Lâilaha, by noting that my circumstances and the universe are not their inner form.

f) Next read: IllaAllâh, by sharpening both eyes and by dictating in the heart that only Allah SWT. It is an essential being.

g) After the nafi-thebat remembrance, it is followed by the Dzikir of calling the name Allâh, Allâh, God in the heart; And familiarized in every situation of everyday life.

h) Finally, the word of Allah, $\mathrm{Hu}$ is lengthened a little uttered while absorbing his inner views, as if he disappeared and also lost memories to other than Allah, including himself, so that only Allah is WajibulWujd. At such a time it is desirable for the descendant of God to be pulled down from him. ${ }^{14}$

The TarekatSammaniyah is among the first Tarekat to have mass followers in the archipelago. The interesting thing about the congregation of the Sammaniyah that may be its trademark is the style of wahdatu al-wujud that is followed and the shahadat uttered by it is not contradictory to the Syari'ah. This conclusion can be proven by attempting to interpret the creed uttered by SyechSamman. And in the book of Manaqib Syech al-Waliyi al-Shahir himself clearly mentioned that SyechSamman is a Sufi who has combined between Syari'ah and Tarekat (aljamibaina al-syari'ahwa al-thariqah).

The Tarekat Sammaniyah is one of the Tarekatthat very familiar in Indonesia. This was conveyed by Nahdlatul Ulama which observed the development of Tarekat in Indonesia by qualifying the existing Tarekat. There are about 45 congregations in Indonesia included in the category Tarekatmu'tabarah. As for the condition of a congregation to be Tarekatmu'tabarah is Tarekat has sanad (chain) that is not interrupted or continued to Rasulullah saw. And therefore legitimate to be practiced.

In Indonesia, the Tarekat of Sammaniyah is very famous especially in Sumatra. In Sumatera, this Tarekat was first developed by Syech 'Abd al-Samad al-

${ }^{14}$ Muhammad Arsyad al-Banjârî, Kanz al-Ma'rifah (t.tp., t.pn., t.tP. ), P. 2-3. 
Palimbani. According to Malay sources, the full name of al-Palimbani is' Abd asSamadibnAbd al-Jawi al-Palimbani, but Arab sources call it Sayyid 'Abd alSamadibn' Abdar-Rahman al-Jawi.

From Tarikh Salasilah Kedah country, as quoted by Azyumardi Azra, alPalimbani was born around 1116/1704 in Palembang and the year of his death is unknown. His father was a sayyid, while his mother was a Palembang woman. This, therefore, corroborates the Arab sources which al-Palimbani is a sayyid. AlPalimbani's father is said to be from Sana'a Yemen, and often travels to India and Java before settling in Kedah and Patani on the Malay Peninsula. Around 1112/1700 he went to Palembang, where he married a local woman and returned to Kedah with his newborn son, al-Palimbani. It is said that al-Palimbani received his early education in Kedah and Patani, perhaps in a cottage (a traditional Islamic educational institution). Later, his father sent him to study in Arabia. But he remains concerned with Islam and Muslims in the Malayo-Indonesian region. In Haramayn, al-Palimbani was involved in the Javanese community and became a fellow of Muhammad Arsyad al-Banjari, Abd al-WahabBugis, Abdar-Rahman al-Batawi, and Daud al-Fatani. His involvement in the Jawi community kept him responsive to socio-religious and political developments in the archipelago.

\section{The Books Used by TarekatSammaniyah}

There are several books that often become a reference in the practice of the Tarekat Sammaniyah, They are:

a. ManâqibWalîAllâhTa'âla al-Syaikh Muhammad ibn 'Abd al-Karîm al- Qâdiry alHasanîal-Sammân al-Madan̂̀

This book was written by K.H. Muhammad ZainiGhani using Malay Arabic script written with 24-page hand, published by Mathba'ahRaudhahBanjarbaru. It is not known exactly when this book was written, but from the source obtained, it is estimated that this book has been around since 1996.15

b. Al-Risâlah al-Nûrâniyyah fi Syarhi al-Tawassulât al-Sammaniyah

${ }^{15}$ Syahriansyah, dkk.,UlamaBanjar, P. 30. 
This book was written by K.H. Muhammad ZainiGhani written in Arabic, as thick as 57 pages, published by Mathba'ahRaudhahBanjarbaru in 1995. The book of Al-Risâlah al-Nûrâniyyah consists of four parts: (1) Introduction, (2) TawassulSammaniyah, (3) SyarhTawassulSammaniyah (4) Conclusion.

\section{c. Al-Imdâd fí AurâdAhl al-Widâd}

This book is published by PT. Al-Zahra Banjarbaru, and experienced several prints. The first printing in $1426 \mathrm{H}$ (2005 AD) and the sixth mold of $1430 \mathrm{H}$. (2009 AD). The contents of the 479-page book with lux cover written in Arabic and some explanations with Arab Malay. As the title of AlImdâdfîAurādAhl al-Widâd, which means helper in the wirid-wirid of experts in affection, the contents are in the form of deeds, or wirid that is practiced in everyday life.

\section{The Lineage of the TarekatSammaniyah}

The lineage of the TarekatSammaniyah obtained by SyechMuda Ahmad Arifin was obtained from SyechMuda Abdul QodimBalubus. The genealogy of TarekatSammaniyah obtained by SyechMuda Abdul QodimBalubus, the pedigree is:

1. Allah swt.

2. Jibril, a.s.

3. Prophet Muhammad saw.

4. AmirulMu' mininSayyidina 'AlīibnAbūṬảlib

5. SyekhSayyidDaud al-Thải

6. SyekhSayyidMa'rūf al-Karakhī

7. SyekhSayyidSirri al-Saqathi ${ }^{\prime}$

8. SyekhSayyid al-Junaidi al-Baghdảd̄̄

9. Syekh al-Dainūrī

10. Syekh Muhammad al-Bakrī

11. SyekhWajih al-Dīn al-Qathī

12. Syekh 'Umar al-Bakrī

13. Syekh 'Abd al-QahīrDiyả al-Dīn as-Suhrawardī

14. SyekhQutb al-Dīn al-Abharī

15. SyekhRukn ad-Dīn Muhammad al-Najjảsȳ̄ 
16. SyekhSyihab al-Dīn al-Abharī

17. Syekh Jamal al-Dīn al-Ahwarì

18. SyekhAbīIshảqIbrảhīm al-Zuhdī al-Kailản̄̄

19. SyekhAkha Muhammad al-Bảsī

20. Pir ‘Umar al-Khalwảtī

21. Syekh Amir al-Khalwảtī

22. SyekhIzz al-Dīn

23. Pir Sadr al-Dīn

24. SyekhAbīZakariyyaYahyả al-Syirwản̄̄

25. Syekh Muhammad al-Nakhảrī

26. SyekhHalabī al-SulțảnīUkarro alias Jamảl al-Khalwảtī

27. SyekhSayyidi Muhammad al-Dīn al-Qustumūni

28. Syekh Ismail al-Jarawi

29. Syekh Mustafa Afandī al-Adranūrī

30. Syekh Imam al-Jali ‘Abd al-Latîf

31. Syekh al-Imam al-'ArifbillahSayyidMustafảKamảl al-Dīn al-Bakrī

32. Syekh Muhammad al-Sammản al-Qadarī al-Khalwảtiyah

33. SyekhHasbì

34. SyekhAbū al-Hasan

35. Syekh Muhammad Amīnibn Muhammad al-Ridwản al-Madīnah

36. Syekh 'Abdar-Rahmản al-Khalidīibn al-KhatibA'limKumangowiyah

37. MaulanaSyekh 'Abdul QadimBalubus. ${ }^{16}$

\section{DISCUSSION}

The purpose of spiritual education in the congregation of Sammaniyah The Learning Assrmbly of ThyaUlumuddinis to know God, to remember Allah, and to witness God by cleansing the heart first, and this can not be separated from the study of Islam, Faith and Ihsan, as well as Syari'ah h Muslims), Tarekat (Islam), essence (Iman), and makrifat (Ihsan), all of which pass through the stages of Dzikir. Furthermore, to achieve the goal of spiritual education must first do repentance from the sins of the birth and the mind. There are 15 (fifteen), 8 (eight) human sins that

${ }^{16}$ Saifuddin, Pemikiran Tasawuf Syech Muda Achmad Arifin Al Haj Sufi Pemurni Tauhid Abad XXI (Jakarta: Hijri Pustaka Utama, 2007), P. 8-9. 
must be cleansed, among which are the sins of birth and the 7 (seven) inner sins. The maqam of the birth $\sin$ is $\sin 1$ ) the eye, 2) the ears, 3) the nose, 4) the mouth, 5) the hand, 6) the legs, 7) the genitals, and 8) the abdomen. As for maqam of inner sin that is 1) Qalbi 2) Spirit, 3) Sirr, 4) Khafi, 5) Akhfa, 6) Nathiqah lust, 7) Kullu bodies.

It must be acknowledged that spiritual education is an effort that leads to the formation of a peaceful, peaceful, serene quality of soul formed with a variety of soul-training exercises in a religious education institution normally led by a teacher with various spiritual methods such as remembrance, riyadah (practice) Closer to God Almighty, and so forth.

As an education that leads to the formation of spiritual and spiritual power, it must be admitted that it is a phenomenon that is implicated in the era of globalization and mental aridity in the modern age as it is stated by SeyyedHusein Nasr that the existential or spiritual crises experienced by man stem from rebellion Modern man to God, that is, when man leaves God in order to establish his existence. The Western society known as "the post-industrial society" is a society that reaches the level of material prosperity of a technologically advanced and automated set of technologies. This luxury is not getting closer to happiness, even more getting caught by anxiety. Modern society has turned into a worshiper of knowledge and technology so unwittingly the integrity of humanity is reduced and trapped in a network of technological rationality systems that are very inhumane. In fact they forget about who they are, to live and where to go afterwards. Thus SayyedHosein Nasr criticizes modernity as he has witnessed in modern society in the West. They lost the vision of divinity and lost the ability to see the reality of life and life intlectus. ${ }^{17}$

A similar phrase is also said Marcel, the loss of boundaries that are considered and believed to be something sacred and absolute cause modern humans who circle in a relative world especially the system of values and morality built. The West has lost its massive super-natural flavor. ${ }^{18}$

A modern culture of liberalization, the rationalization of efficiency consistently continues the process of silting the spiritual life. The liberation that occurs in all aspects of life is nothing but the process of desacralization and de- 
spiritualization of the values of life. In such a process, religions filled with sacred and spiriual values slowly but surely continue to evict from various aspects of community life. Sometimes religion is considered irrelevant and significant in life. As a result, as seen in the general phenomenon of modern society, the spiritual life is getting dry and shallow. ${ }^{19}$

The attempt to liberate modern man through traditional philosophy is Sufism. According to him, the teachings of religion are divided into two categories. The first relates to the aspect of kesyari'ahan or eksoteris and the second is the aspect of sufisme or esoteris. Sufism can not be practiced without first practicing the teachings of Syari'ah h properly. This means that between Syari'ah h and sufism there is a very close relationship. Unity between the two.

Certain ritual practices that must be practiced at all times can maintain a vertical spiritual relationship with God in a communicative situation. It is these rituals that cultivate a spiritual awareness which, in a further stage, manifests itself in noble and noble behavior and morality (ihsan). Sufi awareness, that he always confronts God incites sincere, willing, humble (tawadhu '), patience, trustworthiness, love and so on. ${ }^{20}$

Man is made up of two elements, the first is the body or body, the second is spiritual. The element of the body is passive, dead and has no role to play. The body plays a role because beside it (spiritual element), without the spiritual body is okay, the same as the cut wood, the leaves that fall from the tree. Because the body was a messenger, a servant who obediently and without ever refusing to serve the ruh.tegasnya body like a puppet for the puppeteer. While the second element, believe the spirit is an active element, it is he who feels knowing, receiving, managing, reviewing and concluding. It is this spiritual element that plays a role in moving the body, when, where, for what. The spiritual summarization in man is the element of power, determination, and that is what governs this nature. ${ }^{21}$

In the process of human life that grows and develops, the grown and enlarged are physical to the limits of a certain age. While the developing is spiritual which has no limits of its development.If physical growth in its growth needs to be

${ }^{19}$ Azyumardi Azra, Esei-esei Intelektual Muslim \& Pendidikan Islam (Jakarta, Logos Wacana Ilmu, 1998), P. 100.

${ }^{20}$ Azra, Esei, P. 101.

${ }^{21}$ Kharisuddin Aqib, Inabah (Surabaya: Bina Ilmu, 2005), P. 16-18. 
helped with food and drink. Likewise, spiritual development is evolved from experience and education. Mustafa Zahri said that development is closely related to spirituality even spirituality is a solid foundation for development. For if the spiritually corrupt or evil, then the body is evil, because Rohanilah controls the body in all its actions. Therefore, if this society is to be improved then first spiritual must first be built and nurtured. Therein lays the importance of 'spiritual life'.22

According to Sufi belief people will not get to the essence of the purpose of worship, before taking or executing the road in that direction. The road is called tariqah, in our language pronounced Tarekat, or suluk, and the person who did it called tariqah or salik experts. ${ }^{23}$

In essence, Tarekat is a way of purification of the soul in Sufism pursued by a person or a group of people to get closer to God. Then this way develops and becomes organized institutions in such a way that it becomes a permanent organization. The Tarekat is, therefore, a continuation of Sufi followers' efforts to further specialize the purification of the soul with a system that is guided or institutionalized. In other words, the Tarekat is the formalization of the teachings and practice of Sufism in a more specific form. Sufism as a form of purification of the soul that is individualized transforms into a communal soul purification.

Tariqah is a way or a guide in performing worship according to the teachings exemplified by the Prophet Muhammad and done by friends and tabi'in-tabi'in hereditary up to the teachers in chains until our time. More specifically, the tariqa among Sufis means the system in order to exercise the soul, cleansing of the disgraceful qualities and filling it with the laudable qualities and reproducing the Dzikir sincerely to expect to meet and unite in a spiritual way with the Khaliq, And constantly shy away from something that forgets God. Added by Al-Jurjani 'Ali ibn Muhammad ibn' Ali (740-816 AD), the Tarekat is a special method used by the salik (the traveler) to Allah swt. Through the stages / maqamat.24

${ }^{22}$ Mustafa Zahri, Kunci Memahami IlmuTasawuf, (Surabaya, pt. binailmu, 1995), P. 22

${ }^{23}$ Abu Bakar Aceh, Pengantar Ilmu Hakikat \& Ma'rifat (Solo: Ramadhani, 1995), P. 19.

${ }^{24}$ Khalili Al-Bamar, I Hanafi R, AjaranTarekat: Suatu Jalan Pendekatan DiriTerhadap Allah swt (Surabaya; CV. Bintang Remaja , 1990), P. 10. 


\section{CONCLUSION}

The purpose of spiritual education Tarekat Sammaniyah at Learning Assembly of Ihya Ulumuddin Terrain is to know God, remember God, and watch God (purification of the soul) and taqarrubllallah (nearer to God) by cleansing the liver first, and this is inseparable from the study of Islam, Faith, and Ihsan, as well as Syari'ah h (people / Islam), Tarekat (Islam), the essence (Faith), and makrifat (Ihsan), all passed through the stages in Dzikir. The spiritual education must first repent of the sins of the inner and the inner, the sin that is in the human being which must be cleansed there are 15 (fifteen), 8 (eight), maqam of birth and 7 (seven) maqam of inner sin. The birth is the $\sin 1$ ) the eye, 2) the ears, 3) the nose, 4) the mouth, 5) the hand, 6) the legs, 7) the genitals, and 8) the abdomen. As for maqam of inner sin that is 1) Qalbi 2) Spirit, 3) Sirr, 4) Khafi, 5) Akhfa, 6) Nathiqah lust, 7) Kullu Badni.

Contents/spiritual education materials taught in the Order SammaniyahTaklim Assembly IhyaUlumuddin Medan was about Syari'ah pursued by word and deed, while the congregation, nature, gnosis of which are reached by way of Dzikir (remembrance of Allah). Furthermore, for the remembrance was divided to two things: remembrance oral (zahar), and the remembrance of the liver (qalb / sirr), which has five (5) levels, namely Recitation Ismuzat carried out 5,000 times, Recitation Lathaif that remembrance was done by filling the seven maqam lathaif that in humans, namely: Lathifatul qalbi performed 5000 times, Lathifatur Ruh 1000 times, Latifatus Sirri 1000 times, Latifatul Khafi 1000 times, Latifatul Akhfa 1000 times, Latifatul Lust Natiqah 1000 times, Latifatul Kullu Badni was 1,000 times that amount was 11,000 times, Zikir Nafils batya itu dilakukan by holding the breath along the sentence La ilaha illallah starting from the odd number starts from three, up to twenty one times. Recitation is done repeatedly and usually 21 times Recitation Standing, and DzikirDzikirFanafillah namely the extent that the salik has disappeared / Melting sense keinsanannya into a sense of the divine, he just taste and looked mortal in kebaqaan God. And the zikr has $20 \mathrm{adab}$ in its implementation, of which 5 (five) of them are done before performing Dzikir, 12 when performing Dzikir, and 3 (three) after performing Dzikir.

The method of conveying spiritual education in the Tarekat Sammaniyah of The Learning Assrmbly of Ihya Ulumuddin Medan was by the method 1) bai'atie , taking the oath / promise of a disciple who wants to learn and is an absolute 
requirement in Tarekat, 2) lecturing, is used when the teachers deliver the lessons Related to the Syari'ah, Tarekat, Makrifat, and the procedures associated with it, the last wasthe method 3) Dzikir , in Dzikir there is done 1) Rabithah means to bring the spirit of the teacher (leader of tasawuf) when want to remembrance, because through the teacher we will be able to know God in remembrance, in this rabitah there is a kafi'at, and with this kafia't pupils set in about presenting himself as to know God, 2) Tawajjuh, here a student practices his face with God's face. In short tawajjuh is a method of learning to know, remembering, and witnessing God, and then 3) Khalwat /suluk, practice of Dzikir execution that has been learned or obtained at the time of Tawajjuh. Those who are allowed to do well and have reached the level of Dzikir at the wukuf level, because when it comes to this level, therefore, they will know the procedure of Dzikir under which it is Ismu zat, Lathaif, Nafi isbat.

Suluk is held there are two nights, ten nights, and forty nights. Usually performed on the first 10 days of Muharram month as the first month in Islam, the first male congregation continued with the women's congregation, and the first 5 days to 14 days of Ramadan, and after that followed the male jama'ah, Khalwat / suluk is declared successful, if all participants suluk not violate the rules specified. And suluk does not succeed if there are among participants suluk (Salik) who violate the rules or provisions in implementing seclusion, but the success of all Khalwah / seclusion is determined directly by Syech / Buya.

\section{BIBILIOGRAPHY}

Agustian, A. G. (2001). Rahasia Sukses Membangun Kecerdasan Emosi dan Spiritual (ESQ) Berdasarkan 6 RukunIman dan 5 Rukun Islam. Jakarta: Arga, 2001.

Azra, A. (1998). Esei-esei Intelektual Muslim \& Pendidikan Islam. Jakarta: Logos Wacana Ilmu

Baharuddin, (2007). Paradigma Psikologi Islami; Studi Tentang Elemen Psikologi dari Alquran.Yogyakarta: PustakaPelajar.

Bakar, A. (1995). PengantarIlmuHakikat\&Ma'rifat.Solo: Ramadhani.

Bamar, K. A danHanafi R, (1990). AjaranTarekat: Suatu Jalan Pendekatan Diri Terhadap Allah swt. Surabaya: BintangRemaja.

Boisard, M. A. (1980). L'Humanisme de L'Islam.Terj. Jakarta: BulanBintang

Nahlawi, A. R. (1979). Ushûl al-Tarbiyah wa Asâlibuha fí al-Bait wa al-Madrasah wa alMujtama'. Damsyiq: Dar al-Fikr. 
Nasr, S. H. (1976). Man and Nature: The Spiritual Crisis of Modern Man. London: Mandala Books.

Nasr, S. H. (1991). Islamic Spirituality.New York: Crossroadf

Nasr, S. H. (1994). Islam and the Plight of Modern.Terj. Bandung: Pustaka,

Nasr, S. H. (1994). Traditional Islam in the Modern World.Terj. Bandung: Pustaka.

Saifuddin, (2007).PemikiranTasawufSyechMudaAchmadArifin Al Haj Sufi PemurniTauhid Abad XXI.Jakarta: HijriPustakaUtama.

Sugiyono, (2014). Memahami Penelitian Kualitatif. Bandung: Alfabeta

Undang-Undang RI No. 20 tahun 2003, Tentang Sistem Pendidikan Nasional

Zahri, M. (1995). Kunci Memahami IlmuTasawuf, Surabaya: Bina Ilmu. 